\title{
Discrimination in the Credential Society: An Audit Study of Race and College Selectivity in the Labor Market
}

\author{
S. Michael Gaddis \\ Assistant Professor \\ Department of Sociology \\ UCLA \\ mgaddis@soc.ucla.edu
}

Published in Social Forces*

Keywords: education, credentials, race, discrimination, inequality, employment, labor markets

* This research was supported by a National Academy of Education/Spencer Dissertation Fellowship, a pilot project award from the Department of Sociology at the University of North Carolina at Chapel Hill, and the Jurg Steiner Summer Research Fellowship. Thanks to Karolyn Tyson, Philip Cohen, Arne Kalleberg, Doug Lauen, Ted Mouw, and Devah Pager for their assistance, patience, suggestions, and overall support. Chris Gaddis provided invaluable assistance with the implementation of the data collection methods. Carrie Fox, Jason Freeman, Quaneisha Reynolds, and Amber Wells provided voice recordings for the job candidates' voice mailboxes. Larry D. Schoen provided access to birth record data from New York. Additional thanks to Shawn Bauldry, Kendra Bischoff, Colin Campbell, Betsy Cliff, JD Daw, Paula England, Jennifer Jennings, John Meyer, Ashton Verdery, Brandon Wagner, and the anonymous reviewers for advice and comments on this project. 


\begin{abstract}
Racial inequality in economic outcomes, particularly among the college-educated, persists throughout U.S. society. Scholars debate whether this inequality stems from racial differences in human capital (e.g. college selectivity, GPA, college major) or employer discrimination against black job candidates. However, limited measures of human capital and the inherent difficulties in measuring discrimination using observational data make determining the cause of racial differences in labor market outcomes a difficult endeavor. In this research, I examine employment opportunities for white and black graduates of elite top-ranked universities versus high-ranked but less selective institutions. Using an audit design, I create matched candidate pairs and apply for 1,008 jobs on a national job search website. I also exploit existing birth record data in selecting names to control for differences across social class within racialized names. The results show that although a credential from an elite university results in more employer responses for all candidates, black candidates from elite universities only do as well as white candidates from less selective universities. Moreover, race results in a double penalty: when employers respond to black candidates it is for jobs with lower starting salaries and lower prestige than those of white peers. These racial differences suggest that a bachelor's degree, even one from an elite institution, cannot fully counteract the importance of race in the labor market. Thus, both discrimination and differences in human capital contribute to racial economic inequality.
\end{abstract}




\section{INTRODUCTION}

"Education is the most important determinant yet discovered of how far one will go in today's world.” (1979:3)

--Randall Collins, The Credential Society

The popular notion in U.S. society is that education is the great equalizer. From a young age, children learn that education helps individuals overcome social disadvantage and opens doors of opportunity. But not everyone can go to college and those who do enter into a tiered system of schools and exit into a labor market that values more than educational credentials. Although education scholars document the ways that institutions at the primary and secondary levels reinforce a stratified system with deep racial divides in outcomes, scholars have devoted less attention to differences among college graduates.

Some research highlights the discouraging finding that racial economic inequality is greatest among the college-educated (Cancio, Evans, and Maume 1996; Zhang 2008). This finding perhaps is explained by the stratified higher education system in the U.S.; blacks, Hispanics, and low-income students are much less likely to attend highly selective institutions than whites, Asians, and high-income students (Alon and Tienda 2007; Bowen and Bok 1998; Carnevale and Rose 2003). However, it is unclear how much employers value degrees from highly selective institutions and if there are racial differences in the returns to these degrees (Brewer and Ehrenberg 1996; Dale and Krueger 2002, 2011; Zhang 2008).

Rather than serve as the great equalizer, a higher education credential, even one from a highly prestigious institution, may not fully erase employer biases - implicit or explicit - against blacks. Since the passage of the Civil Rights Act, researchers have consistently found evidence of racial discrimination in the labor market using a variety of methods (Bendick, Jackson, and Reinoso 1994; Bertrand and Mullainathan 2004; Kirschenman and Neckerman 1991; Pager 
2007a). No research, however, has explored whether employers engage in racial discrimination against applicants with prestigious college degrees. Such research would increase our understanding of the possibilities and limitations of education in reducing social inequality.

In this article, I examine the employment opportunities for white and black graduates of elite versus less selective institutions to determine if racial economic inequality among the college-educated is explained by racial differences in human capital, racial discrimination in the labor market, or both. Unfortunately, nationally representative data have fallen short in addressing these issues. Some potentially important human capital measures, such as college selectivity, GPA, and major, are often not available. Moreover, while researchers in the 1980s and early 1990s were able to assess employers' thoughts on discrimination through surveys and interviews, legal concerns and social desirability bias have reduced the viability of these methods in assessing discrimination today. Using field experiments, researchers can control for human capital and race, and more closely examine employer decision processes. Thus, an audit study is well-suited to examine racial economic inequality among the college-educated.

I conduct an audit by matching candidate pairs and applying for jobs listed on a national job search website. In total, I apply for 1,008 jobs in three geographic regions in the U.S. to examine how race and college selectivity affect the likelihood of receiving an employer request via e-mail or phone for a job interview. Then, among those job candidates receiving responses, I analyze how race and college selectivity influence candidates' potential salary range and occupational type. The results suggest that higher education credentials do not equalize employment opportunities for blacks compared to whites, even among elite university graduates. Credentials from an elite university result in more call-backs for all candidates, but black candidates from an elite university only do as well as white candidates from a less selective university. Moreover, race results in a double penalty: when employers respond to black 
candidates it is for jobs with lower starting salaries and lower prestige than those of white peers. These racial differences suggest that even a bachelor's degree from an elite institution cannot fully counteract the importance of race in the labor market. Thus, both discrimination and differences in human capital contribute to racial economic inequality among the collegeeducated.

\section{BACKGROUND AND THEORY}

There is no denying that college degrees generally yield economic benefits. Individuals with a bachelor's degree have $66 \%$ higher expected lifetime earnings and are less than half as likely to be unemployed than individuals with a high school diploma (Baum, Ma, and Payea 2010). However, racial inequality is prevalent among college graduates; black men make approximately $75 \%$ of the wages of white men and black women make approximately $90 \%$ of the wages of white women (Bradbury 2002). In fact, racial differences in earnings (Cancio, Evans, and Maume 1996; Zhang 2008) and unemployment (Wilson, Tienda, and Wu 1995) are highest among those who hold a bachelor's degree. This racial inequality incites a rich debate over whether the source is human capital differences (Heckman 1998; Neal and Johnson 1996) or employer biases and discrimination (Lucas 2008; Pager 2003).

\section{Racial Inequality due to Differences in Human Capital}

Scholars in the human capital tradition argue that employers look to make the best possible investments when hiring employees and choose those with measurable superiority. Among high school graduates, employers choose white over black candidates at higher rates due to differences in high school quality, curriculum, and other indicators of human capital (Farkas and Vicknair 1996; Heckman 1998; Neal and Johnson 1996; O'Neill 1990). Racial discrimination is often downplayed. Nobel Prize-winning economist James Heckman called racial discrimination “the problem of an earlier era” (1998:102). 
At the heart of this research is an effort to explain differences in outcomes based on a number of variables such as knowledge, IQ, effort, and experience. Critics point out that these models fail to explain how employers determine applicants' abilities apart from their educational attainment and often fail to capture important mechanisms (Tomaskovic-Devey, Thomas, and Johnson 2005). Recent research that attempts to more accurately model these processes finds racial differences in the return to education after accounting for human capital (Alon and Haberfeld 2007; Tomaskovic-Devey, Thomas, and Johnson 2005).

College selectivity is one potentially important human capital explanation for racial inequality. The most selective colleges admit smaller percentages of black students than less selective colleges (Soares 2007:174-5) and black students are also much less likely than white students to attend and graduate from highly selective institutions (Alon and Tienda 2007; Bowen and Bok 1998; Carnevale and Rose 2003). However, employers must place a higher value on credentials from selective institutions for this racial difference to manifest as economic inequality. Research on the effects of college selectivity is somewhat mixed. Comparisons of broad categorical classifications show some positive effects of college type on occupational status and income (Brewer, Eide, and Ehrenberg 1999; Monks 2000), while other results show that students at more selective colleges are more likely to graduate, more likely to attend graduate or professional programs, and earn higher wages (Alon and Tienda 2005; Bowen and Bok 1998; Brand and Halaby 2006; Brewer and Ehrenberg 1996). Social capital and institutional networks at elite schools also benefit graduates (Mullen 2010; Rivera 2011).

Non-experimental data, though, are subject to potential bias due to correlations between unobserved factors, such as student ability and motivation, that may influence both admission to selective colleges and outcomes such as graduation and wages (Dale and Krueger 2002, 2011; Gerber and Cheung 2008). Scholars using more sophisticated methods to address selection bias 
find mixed results about the effect of college selectivity. Black and Smith (2004) match similar individuals from different institutions using test scores and find that college selectivity has a positive effect on wages. Using a regression discontinuity design, Hoekstra (2009) finds that white men who barely made the admissions cut-off at a flagship state university experience $20 \%$ higher wages than white men who barely missed the admissions cut-off. Dale and Krueger (2002) use the College and Beyond Survey to examine wage returns 15 years after graduation and find no effect of college selectivity when matching students based on institutions they were admitted to but did not attend. In a follow-up, Dale and Krueger (2011) include an additional cohort and again find no effect of college selectivity on earnings after adjusting for selection. Additional research presents mixed conclusions on the existence and size of selection bias (Behrman et al. 1996; Long 2008).

Thus, it is somewhat unclear whether college selectivity has a causal effect on labor market outcomes. If racial differences in the qualitative aspect of educational credentials, i.e. college selectivity, explain racial economic inequality then establishing the effect of college selectivity is paramount. This leads to my first research question: (1) Does college selectivity affect labor market outcomes?

\section{Racial Inequality due to Discrimination}

Research using a variety of methods has found evidence of racial discrimination at various stages of the labor market, particularly for low-wage job seekers. These studies have documented the role of employer attitudes toward and opinions of blacks (Kirschenman and Neckerman 1991; Moss and Tilly 2001; Waldinger 1997), the role of racially-targeted recruitment (Braddock and McPartland 1987; Moss and Tilly 2001; Kirschenman and Neckerman 1991), and racial differences in employment outcomes using experimental methods (Bertrand and Mullainathan 2004; Pager 2003, 2007a; Pager, Western, and Bonikowski 2009). 
Unfortunately, these studies do not reveal whether higher education credentials attenuate racial discrimination.

Explicit examination of labor market discrimination is an important but difficult endeavor for social science research. Although there are clear merits to Title VII of the Civil Rights Act of 1968, which gives individuals the right to sue discriminatory employers, it appears to have made identifying discrimination more difficult without entirely eliminating it. As Doug Massey states, "when pushed by the federal government to end overt discriminatory practices, [whites] are likely to innovate new and more subtle ways to maintain their privileged position in society.” (2007:54). Researchers are presented with the methodological puzzle of adopting new ways to measure something that can no longer be directly observed.

Direct questions about prejudiced attitudes and beliefs are less valuable today than in the past. Research finds increasingly lower affirmative response rates to such questions (Bobo 2001; Schuman et al. 2001; see also, Blank et al. 2004). One reason is the development of a social consciousness regarding such attitudes and beliefs, or social desirability bias (Pager and Quillian 2005). Individuals may present a public facade about non-whites that hides their true opinions (Bonilla-Silva 2010). Additionally, although information collected from surveys on attitudes can be important it says nothing of discriminatory actions (see Pager and Quillian 2005).

Thus, many scholars have relied on statistical residuals to examine discrimination. Discrimination is assumed when there is an otherwise unexplainable racial difference on a dependent variable (Lucas 2008). Often, scholars must account for as many important variables as possible and defend the residual as an estimated effect of discrimination based on observables. This method is hindered by a number of serious problems including omitted variable bias, sample selection bias, and inadequate measurement of cumulative discrimination effects (Blank et al. 2004; Jones and Kelley 1984; Lucas 2008; Quillian 2006). Omitted variable bias can lead 
to improper attribution of the residual to the effect of discrimination. For example, if human capital is not adequately measured and there are mean differences in human capital between whites and blacks, the effect of the omitted variable (human capital) is incorrectly attributed to discrimination. Residual attribution presents uncertainty, so some researchers have turned to field experiments, arguing that they represent a vast improvement over standard observational models to examine discrimination.

Some research explores racial heterogeneity in the effects of human capital and finds a mix of larger positive effects (Dale and Krueger 2011; Loury and Garman 1995), no differential effects (Long 2010; Monks 2000), or smaller positive effects (Cooper and Cohn 1997) of college selectivity on wages for blacks compared to whites. Others have found that individuals least likely to attend college receive the largest economic benefits from college (Brand and Halaby 2006; Brand and Xie 2010; see also, Hout 2012).

Observational research makes it unclear if racial discrimination occurs among bachelor’s degree holders and whether college selectivity attenuates potential discrimination. These issues lead to my final two research questions: (2) Does race affect labor market outcomes among bachelor's degree holders? and (3) Do race and college selectivity have an interactive effect on labor market outcomes?

\section{Using Audit Studies to Examine Labor Market Outcomes}

An audit study is a field experiment that matches two individuals with nearly identical characteristics to test an outcome. Audit research began with in-person examinations of housing discrimination in the 1970s (see Yinger 1995) but audits have evolved to include correspondence by mail and computerized (online correspondence) versions. Researchers may properly attribute differences in outcomes due to careful sampling and randomization along with matching on important criteria between auditors. The audit method has grown in popularity, particularly to 
examine racial discrimination, with the rise of online applications for housing and employment. In recent years, sociologists, economists, and political scientists have implemented creative and influential computerized audit studies (e.g. Ahmed and Hammarstedt 2008; Butler and Broockman 2011; Hogan and Berry 2011; Lauster and Easterbrook 2011; Tilcsik 2011).

In-person audits require human assistants to participate in the research process. Critics of the in-person method suggest that researchers are unable to control for important characteristics that may differ between individuals, such as delays in speech, differences in poise, etc.; in other words, differences in characteristics that employers can witness but the researcher cannot (Heckman 1998; Heckman and Siegelman 1993). By removing the human element of the audit, researchers may alleviate many of these problems.

Although in-person audits use personal appearance to convey race, correspondence and computerized audits must rely on written information to convey race. Research often uses racialized names, but scholars have raised concerns that these names may conflate race and social class and bias the results (Fryer and Levitt 2004; Pager 2007b). Despite some ex post facto examinations, no research has incorporated race and social class of names directly into the design stage of the study.

The choice of audit type must align with standard practices in the real world. For instance, audits of the low-wage labor market require an in-person method because these jobs are not traditionally listed online. By contrast, a broad range of jobs targeted toward the collegeeducated require candidates to apply online. A computerized audit study closely mimics the real experiences of college-educated job seekers today as employers are increasingly less likely to accept job applications in-person or by mail.

\section{DATA AND METHODS}


Between March and August of 2011, I conducted a computerized audit study following four general steps (detailed below): I (1) created a series of candidate profiles varying race, gender, social class, college selectivity, and college major, (2) carefully matched candidate profiles, (3) selected and applied to jobs in three geographic regions in the U.S., and (4) recorded employer responses.

Creating Candidate Profiles - College Selectivity, Race, and Social Class

To examine college selectivity, I selected elite universities that ranked highly in both the U.S. News and World Report and Baron's rankings and paired them with a nationally ranked but less selective university ranked below the elite university (U.S. News and World Report 2011). I used the following pairs: (1) Harvard and University of Massachusetts - Amherst, (2) Stanford and University of California - Riverside, and (3) Duke and University of North Carolina Greensboro. $^{1}$

I obtained data from the New York State Department of Health on births during the early 2000s that list the total number of births by (1) name and race and (2) name and mother's education. I searched for first names with at least 50 births per year in the state and at least $75 \%$ born to mothers of one particular race (black or white). I then chose names from this list that were similar on mother's education to select three names for each race and gender combination representing three tiers of education levels (upper, middle, and lower). In total, I used 12 different names: Jalen, Lamar, and DaQuan (black/male); Nia, Ebony, and Shanice (black/female); Caleb, Charlie, and Ronny (white/male); Aubrey, Erica, and Lesly (white/female). I then selected last names using frequently occurring surnames from the 2000 Census which were approximately race neutral (U.S. Census Bureau 2008) (see Appendix Table A1 and the online appendix for more information on first and last names respectively). 
There are potential shortcomings from using these names. First, names in New York may not be representative of the U.S. population. I attempt to limit these differences by not selecting any obvious immigrant or black Muslim names. Second, the time period of the names data is not perfectly aligned as individuals graduating from college in 2011 were born around 1989.

Although the social class or racial naming patterns of these 12 names may have changed over a decade, data limitations prevent me from exploring this issue. ${ }^{2}$

\section{Creating Candidate Profiles - Resumes, Cover Letters, and Other Information}

To create candidate resumes, I combined elements of actual resumes used by job seekers prior to data collection. I used two style templates to create resumes (each candidate could be assigned either template but each job had two applicants with different templates), entered the candidate information, and instituted random assignment across pertinent variables.

I created two basic resumes each with a short objective statement, four to five activities in student organizations with two leadership roles, a list of skills, and an employment history. Each list of activities came from real organizations on each campus and was matched as closely as possible across campuses. Listed skills matched with those used or reasonably attained in the specified employment history. Finally, each candidate’s employment history included work in one typical part-time student job (e.g. sales, wait staff) and one internship position using real employers with offices in every region. The total time of employment across candidates was the same.

To examine additional human capital differences ${ }^{3}$ that may contribute to race and gender inequality in observational studies, I used two possible college majors for each resume: economics and psychology. Each of these majors is one of the top choices by gender for men and women respectively (Altonji, Blom, and Meghir 2012; Carnevale, Strohl, and Melton 2011). 
Furthermore, these majors provide general knowledge and skills that can be used to apply for a broad range of jobs.

I then created two different cover letters to assign to each candidate. The overall content of each cover letter was the same, but I altered the specific words, phrases, and order. Each cover letter contained information on college courses, leadership experience, skills, and an explanation that the candidate had recently relocated from their college town to a residence local to the employer. Finally, I randomly assigned cover letters prior to the job application process so that a matched pair never used the same cover letter.

For each candidate/school combination, I obtained a unique telephone number with a local area code and a voice mailbox using Google Voice, a Google e-mail account, and a mailing address. Individuals matching the race and gender of the candidate recorded identical outgoing voicemail messages apart from the candidate's name. Because employers might be aware of differences in rental prices in local areas, I used Google to investigate apartments and select an address for each candidate (also adjusted for cost of living across regions).

\section{The Matching Procedure}

An advantage of the audit method is that a researcher is able to isolate the difference on a single characteristic between testers in a matched pair to examine the effect of that characteristic. Critics suggest that a variety of unmeasured differences may exist between testers and matches between testers with a single difference may inflate the importance of that difference (Heckman 1998; Heckman and Siegelman 1993). Careful design in a computerized audit reasonably removes any concern of unmeasured differences. The use of multiple measured differences may sometimes be useful; prior audit studies have both intentionally and unintentionally examined two measured differences between testers in a matched pair (e.g. Ahmed and Hammarstedt 2008; Bertrand and Mullainathan 2004). 
In this study, a number of conditions led me to simultaneous vary two characteristics within matched pairs. To examine college selectivity as the singular difference, I would need to simultaneously hold race, gender, and social class constant within pairs. However, the nature of the measurement of these variables would require that candidates have the same first name. Employers likely would be more suspicious of two applications received within days of each other with the same distinctive name (particularly black names), possibly eliminating both candidates from consideration. To examine race as the singular difference, a similar problem arises because employers likely would be more suspicious of two applicants with the same degree from the same college (particularly elite schools). Results from a pilot study confirm that these options increase the likelihood of experiment discovery and bias the results by reducing the overall sample size in an unmeasurable way. ${ }^{4}$ Thus, I chose to simultaneously vary both characteristics within pairs and made matches on the basis of gender, social class, major, and region. Table 1 shows the 24 core matched pairs. ${ }^{5}$

This design is very similar to the traditional design of a factorial experiment as all twoby-two combinations are represented in the data (Gonzalez 2009). However, unlike the traditional experimental design, audit studies derive overall effects from a combination of withinpair and between-pair effects. ${ }^{6}$ Traditional experiments randomly assign individuals to either a treatment or control condition and examine all individuals on the same outcome measure. Audit studies use a similar approach but often include random assignment of pairs to social actors or situations which then form the basis of the outcome measure. For example, housing audits randomly assign pairs to real estate agents and employment audits randomly assign pairs to employers. No single real estate agent or employer creates the outcome measure for more than one pair. Thus, between-pair comparisons are unbiased, although the estimates are less efficient than within-pair comparisons, when a researcher institutes proper random assignment of pairs 
and verifies that no significant differences across social actors or situations exist (see Pager 2003, p 957).

By examining a combination of within-pair and between-pair effects with random assignment of employers to matched pairs, this research closely approximates a similar design to using four candidates per job (black/elite degree, black/less selective degree, white/elite degree, white/less selective degree) but without the limitations and ethical concerns previously discussed. An additional advantage of this design is that employers do not focus on a single difference between candidates. It is highly unlikely that employers in real world scenarios have to make the unrealistic choices that the typical matched pair process requires of them, potentially inflating the estimates of characteristics such as race in prior audits.

\section{Selecting and Applying to Jobs}

For two separate weeks during May and June 2011, I used a programming script that I wrote in Ruby to query the employment website and download all posted jobs in the cities in my three selected regions that fit the following search criteria: college degree (BA) required, listed as “entry level” or "student”, posted in the past 30 days, and located in a 50 mile radius of the cities. I then eliminated any jobs that required the applicant to leave the website and apply at an external site and those that required specialized degrees or training (e.g. nursing, engineering, etc.). The script saved the data into a text file and the HTML file for each job listing. This became the sampling frame for each region. In each sampling frame I generated a random number for each job, ordered them, and kept the first 336 jobs to create my three samples across regions. With the jobs randomly ordered, I assigned pair IDs (see Table 1) to each job and split the application order across pairs.

Once I matched jobs and candidates for a particular geographic region, I applied for 240 jobs (2 candidates per job) in each home region (e.g. Boston and New York City for Harvard and 
UMass graduates) and 96 jobs in one of the two outside regions. I implemented a 24 hour delay between the first and second applications to reduce the chance of employer discovery. In total I applied for 1,008 jobs (2,016 data points). I then waited for ten weeks after the submission of each application for employers to make decisions and respond to candidates before concluding the data collection phase.

\section{Descriptive Results}

Table 2 shows descriptive statistics for the candidates by order of application. There is an attrition rate of 5.6\% due to employers removing a job advertisement before one or both candidates could apply for the job. Of the 952 successful candidate pairs submitted, there are equal numbers of candidates across race and college selectivity. The remaining variables differ between pairs so some characteristics are not evenly divided due to attrition.

Employers responded to job applications from candidates in one of three ways: email, phone, or both. ${ }^{7}$ Employers used email to solicit additional information or setup a time for a phone or in-person interview. When employers called candidates, they almost always requested an interview. Generally, emails were less urgent and represented an additional interim stage before a phone call (e.g. "Please fill out this questionnaire if you wish to still be considered for this position.”) while phone calls were more urgent and represented a more advanced stage in the process than emails (e.g. "We would love to hear back from you as soon as possible with a time that works best for you.”). Occasionally, employers responded to both candidates with a generic email that did not indicate a clear interest. ${ }^{8}$ As Table 2 shows, the average response rates were 7.4\% by email, $8.2 \%$ by phone, $3.5 \%$ by both, and $12.1 \%$ total.

Table 3 shows descriptive statistics for the job advertisements by application set. Set 1 refers to a black candidate with an elite degree and a white candidate with a less selective degree (Pair IDs 1-12 from Table 1); set 2 refers to a white candidate with an elite degree and a black 
candidate with a less selective degree (Pair IDs 13-24 from Table 1). Each job advertisement or employer received applications from only one pair, creating a different sample of jobs for each set. However, Table 3 indicates that the different sets did not apply for significantly different types of jobs in respect to occupational category, listed salary ranges, or by rate of attrition. The sample of jobs each set applied to are approximately 23\% sales, 17-19\% customer service, 15\% administrative assistant, 9-10\% analyst, 8-9\% clerical, 5-6\% human resources, 5\% managerial, and $13-16 \%$ other categories. Set 1 applied for jobs with listed starting salary ranges averaging between $\$ 31,000$ and $\$ 37,600$ and set 2 applied for jobs with listed starting salary ranges averaging between $\$ 31,800$ and $\$ 37,900$. Finally, the attrition rates are similar; $6.2 \%$ of job advertisements for set 1 and $5.0 \%$ for set 2 .

\section{Methods of Analysis}

For simple bivariate analyses, I use a two-tailed paired t-test to test for significant differences within pairs from the same sample (Kutner, Neter, Nachtsheim, and Li 2004). However, to examine between-pair effects I use a less efficient estimator because the sample and sample size varies between the two groups. The Welch's t-test is appropriate with two independent samples of unequal sample size and unequal variance (ibid).

A logistic regression equation predicting odds-ratios controls for all observed characteristics, returns estimates that are weighted based on the small differences due to attrition, and allows for cluster-corrected standard errors at the employer level:

$$
\operatorname{logit}\left(p_{i}\right)=\alpha_{i}+\beta_{1} C S_{i}+\beta_{2} R_{i}+\beta_{3} S C_{i}+\beta_{4} G_{i}+\beta_{5} M_{i}+\beta_{6} R_{i}+\beta_{7} X_{i}+u_{i}+e_{i j}
$$

In the equation above, $\alpha_{\mathrm{i}}$ is the individual-level intercept, the $\beta$ coefficients 1-6 represent the coefficients for college selectivity, race, social class, gender, college major, and region, 
respectively, $X_{\mathrm{i}}$ represents a vector of control variables, $\mathrm{u}_{\mathrm{i}}$ is the individual-level error term, and $\mathrm{e}_{\mathrm{ij}}$ is the employer-level error term.

Among only those candidates who receive responses for jobs that include a listed salary range, I run OLS regression models to examine differences in these listed salaries:

$$
Y_{i}=\alpha_{i}+\beta_{1} C_{i}+\beta_{2} R_{i}+\beta_{3} S C_{i}+\beta_{4} G_{i}+\beta_{5} M_{i}+\beta 6 E_{i}+\beta_{7} X_{i}+u_{i}+e_{i j}
$$

In the equation above, $\mathrm{Y}_{\mathrm{i}}$ is one of three possible variables that captures information about the salary range: the lowest listed value in the range, the mean of the range, or the highest listed value in the range. I run three separate regressions, one for each possible listed salary outcome variable.

Finally, among only those candidates who receive an employer response, I run logistic regression models predicting whether the response is for an analyst or managerial job versus all other jobs:

$$
\operatorname{logit}\left(p_{i}\right)=\alpha_{i}+\beta_{1} C S_{i}+\beta_{2} R_{i}+\beta_{3} S C_{i}+\beta_{4} G_{i}+\beta_{5} M_{i}+\beta_{6} R_{i}+\beta_{7} X_{i}+u_{i}+e_{i j}
$$

\section{RESULTS $^{9}$}

Employer Responses by College Selectivity and Race

The first two figures show the bivariate results of employer responses (email, phone, and total response percentages) by the two main characteristics of interest: college selectivity and race. ${ }^{10}$ Figure 1 shows that candidates with a degree from an elite university receive more email responses than candidates with a degree from a less selective university at a rate of approximately 1.4 to 1 (8.7\% vs. 6.1\%). This difference is larger when examining phone 
responses from employers: 1.9 to 1 (10.7\% vs. 5.7\%). The results examining either an email or phone response (total response) from employers show that candidates with a degree from an elite university are 1.7 times as likely to get any response as candidates with a degree from a less selective university (15.2\% vs. 8.9\%). In all cases, a two-tailed Welch's t-test shows that the differences in means are statistically significant $(\mathrm{p}<0.05$ for email; $\mathrm{p}<0.001$ for phone and total responses).

Figure 2 reports employer responses for white versus black candidates. White candidates receive more email responses than black candidates at a rate of approximately 1.4 to 1 (8.7\% vs. 6.1\%) and more phone responses at a rate of approximately 1.6 to 1 (10.0\% vs. $6.4 \%)$. For total responses from an employer, white candidates are 1.5 times as likely to get a response as black candidates (14.5\% vs. 9.7\%). These results are significantly different between the two racial categories ( $\mathrm{p}<0.05$ for email; $\mathrm{p}<0.01$ for phone and total responses).

These results tentatively suggest that both educational credentials and race are important; both have strong relationships with the rate of employer responses. Due to the small differences in attrition across the two samples of job advertisements, it is important to examine logistic regressions predicting employer responses. The results of these models, shown in Table 4, closely match those of the bivariate figures. Compared to whites, blacks are $62.8 \%$ as likely to receive any type of employer response. Candidates with a degree from an elite university are $184.1 \%$ as likely as candidates with a degree from a less selective university to receive any type of employer response.

Overall, these results suggest that employers strongly value a degree from an elite university but also discriminate against candidates with black names. An additional area of inquiry is how these variables work together. For instance, can black candidates close the gap 
with white candidates when they have a degree from an elite university compared to a degree from a less selective university?

In Figure 3, I examine total employer responses across race and college selectivity. These results suggest a tiered pattern of responses: white candidates with a degree from an elite university have the highest response rate (17.5\%), followed by black candidates with a degree from an elite university (12.9\%) and white candidates with a degree from a less selective university (11.4\%) ${ }^{11}$, and finally black candidates with a degree from a less selective university have the lowest response rate (6.5\%). ${ }^{12}$ Thus, a white candidate with a degree from an elite university can expect an employer response for every 6 resumes submitted, while an equally qualified black candidate must submit 8 resumes to receive a response; white candidates with a degree from a less selective university need to submit 9 resumes to expect a response, while a similar black candidate needs to submit 15 resumes to receive a response.

In other logistic regression models (results available upon request), I explore potential interaction effects of race and educational credentials. In multiple model specifications the interaction effect of black candidate and degree from an elite university is positive although never statistically significant. These results suggest that, compared to white candidates, black candidates do not gain more or less from a degree from an elite university over a degree from a less selective university.

\section{Listed Salary Range of Jobs by College Selectivity and Race}

Educational credentials and race affect employer response rates, but the effects extend beyond the number of responses a candidate receives. Candidates are sorted through a system that presents or restricts opportunities in multiple ways. Two additional pieces of information from the job advertisements are the dependent variables in the following sections: the listed salary range and the occupational category of each job. 
When employers post a job advertisement they include a variety of information to attract job candidates. In 289 cases in the sample (30.4\% of the job advertisements), employers included information about the salary range. As previously mentioned, I created three variables for listed salary: low, mean, and high values from each job advertisement (see Table 3). Among those candidates who receive any type of response from an employer, 93 cases come from a job advertisement with a listed salary range (40.4\% of the responses). ${ }^{13}$

Table 5 reports the effects of candidate and application characteristics on these salary variables from three OLS regressions. ${ }^{14}$ Using the low salary variable (model 1) I find that black candidates receive responses for jobs that have a listed salary \$3,071 lower than white candidates. Candidates with a degree from an elite university receive responses for jobs that have a listed salary \$2,601 higher than candidates with a degree from a less selective university. In models 2 and 3, I find similar results when the outcome is mean or high salary but the coefficient for black candidate is not significant in model 3.

The results from Table 5 suggest that black candidates face a double penalty of discrimination in the labor market. Not only are they less likely to receive a response than white candidates, but the jobs that are potentially available to them are listed with $~ 10 \%$ lower starting salary ranges. Conversely, candidates with a degree from an elite university get a double bonus from their educational credentials in the labor market in the forms of more responses and 8-13\% higher listed salary ranges.

\section{Occupation Type by College Selectivity and Race}

One final way to analyze labor market opportunities is to examine the differences in occupational categories of job advertisements for which candidates receive responses. Although there are a number of ways to quantify the "best" occupational categories among those in the sample, I use two criteria: educational credential requirements and listed salary range. All of the 
job advertisements in the sample require a college degree but two occupational categories more consistently list this requirement than others: analyst and managerial. Moreover, these two occupational categories have higher average listed salary ranges than others. ${ }^{15}$ I deem these two occupational categories "high value” and compare responses against all other categories. 142 of the 952 job advertisements (14.9\%) are high value occupations.

I run logistic regression models predicting whether an employer response is for a high value occupation or not using a sample that only includes candidates who receive any type of employer response. The first two models of Table 6 show the results from these regressions. In the first model, I find that black candidates are $56.1 \%$ as likely as white candidates to receive a response for a high value occupation vs. other occupations. No other variables of note are statistically significant, including the coefficient for a degree from an elite university. In model 2 I control for whether both applicants received a response and find no significant changes in the effects across models. In sum, one out of every four responses for a white candidate was for a high value occupation while one out of every six responses for a black candidate was for a high value occupation.

As a final test, I run logistic regressions predicting whether an employer response is for a customer service occupation (18.2\% of the sample) or not. Only candidates who receive any type of employer response are included. The third and fourth models of Table 6 show the results from these regressions. These two models show that candidates with a degree from an elite university are 53-56\% as likely to receive as likely as candidates with a degree from a less selective university to receive an employer response for a customer service job. Race and all other variables are not statistically significant in these models. ${ }^{16}$

\section{Employer Sentiment about Elite Universities}


Beyond employer contact with candidates, employers also exchanged internal emails among themselves. In thirteen cases, employers accidentally included candidates on correspondence that was intended for other employees of the company, presumably in the human resources department. Most of these emails were forwarded versions of the brief email with limited candidate information that is sent to employers notifying them of a new application. Typically, the sender included a sentence indicating that the intended recipient should examine a particular candidate. In five cases these messages, in an excited or urgent tone, explicitly mentioned the institution from which a candidate held a degree:

1. "ok, she had me at Stanford. Eat our dust [competitor]." - referencing white female applicant

2. "forget the others: HARVARD GRAD" - referencing white male applicant

3. "Kids coming out of Duke are by far the most capable. Push this one to the top of the list."

- referencing black female applicant

4. "Harvard guy wants to work for us!" - referencing white male applicant

5. "We had a real bright app pop up this morning - Stanford grad with great credentials.” - referencing white male applicant

These accidental emails provide some limited qualitative insight into the importance employers place on a degree from an elite university. In zero of the thirteen cases did an 
employer explicitly mention one of the less selective universities, race, gender, or any other characteristics. Thus, it is likely that the signal of an elite credential is at the forefront of employers’ minds.

\section{DISCUSSION}

As higher education credentials become more common in the labor market, an examination of labor market outcomes among individuals with a college degree is critical to understanding education's role in reducing or exacerbating inequalities. One goal of this study was to examine the effects of college selectivity on early stage job market outcomes for recent college graduates to add clarity to the debate on the importance of qualitative aspects of human capital. The results suggest that a degree from an elite university increases the likelihood that an employer will respond to a job application with an offer for an interview and those responses are for jobs with higher listed salaries. Human capital, operationalized as college selectivity, clearly matters in the job market.

Scholars have questioned whether racial economic inequality is the product of racial heterogeneity in human capital or racial discrimination. However, data limitations have precluded examinations of qualitative differences in human capital among the college-educated. Since whites are more likely than blacks to have a degree from an elite university (Alon and Tienda 2007; Carnevale and Rose 2003), the results of this study suggest that at least part of racial economic inequality can be attributed to differences in educational credentials.

Yet, these results suggest that discrimination also plays a large role in employer decisions. Just as audit studies have uncovered racial discrimination in the low-wage labor market (Pager 2003; Pager, Western, and Bonikowski 2009), I find significant evidence of racial discrimination in a section of the labor market that demands highly educated employees. The opportunities that arise upon graduation from an elite university are not equal between whites and blacks. 
Although there is clearly a premium to a degree from an elite university over a less selective university for both white and black candidates, black candidates still lag behind white candidates in employer responses. Additionally, when black candidates receive responses, they are for jobs with lower listed salaries and less often for managerial or analyst jobs. Thus, even if we assume that black candidates could simply work harder and apply to many more jobs than their white counterparts, inequality would still pervade the labor market.

Surprisingly, there is no interaction effect between race and college selectivity; the blackwhite gap in employment outcomes is similar for both types of degrees. The results presented here suggest a different picture than the romanticized idea that education is the great equalizer. On a number of quantitative and qualitative aspects, blacks are at a disadvantage compared to their white peers. While both whites and blacks may be able to alter their educational trajectories to improve the name of the institution on their college degree, blacks can never shed the penalty of race and catch up to whites.

This research has important implications for the current debate regarding affirmative action in higher education. Using data prior to statewide bans on affirmative action, researchers have estimated that minority enrollment at highly selective public universities nationwide would drop without affirmative action policies (Bowen and Bok 1998; Espenshade and Chung 2005). Other studies have found that after California, Texas, and Washington implemented bans on affirmative action, state university systems began to look more racially stratified with whites and Asians at the highly selective flagship universities and blacks and Hispanics at less selective universities (Brown and Hirschman 2006; Card and Krueger 2005; Long 2007). Fully eliminating race-based affirmative action in higher education would likely guarantee that fewer black students would attend and graduate from highly selective public universities and thus lead to increased racial inequality in employment and wages between whites and blacks. 
Unfortunately, one significant shortcoming of audit studies is the inability to examine the entire employment process. In this case, I cannot see how the employer sorting process might play out through the interview and job offer stage. It is unclear once employers meet a candidate face-to face how they might respond to a candidate's race with both offers of employment and salary. Likely, some employers do not pick up on the racial cues from an individual's name and the levels of discrimination reported here might be underestimated. This study, however, presents a clear picture of the opportunity structure for candidates in the initial stages.

It is also unclear how much the use of the computerized audit method and an online national job search website affect the results. The overall effects of college selectivity estimated here are likely conservative; previous research finds that some benefits of attending a highly selective institution come through the social capital and networks made available from those institutions (Rivera 2011). These effects are not captured through an audit as applicants apply with no prior contact through such networks. Social capital may not only increase any main effects of college selectivity but also potentially exacerbate any racial differences. However, Dale and Krueger (2011) suggest that social capital might be the reason why they find positive effects of college selectivity for minorities and low-income students in their survey data. Future research should explore these possibilities.

Alternatively, if employers using the website do not often see candidates with a degree from an elite university in their applicant pool, these results may be overstated compared to the effect of college selectivity across all hiring processes. Two studies suggest that, at the very least, it is a common practice for both employers and job seekers to use the internet to search for employment opportunities. First, a recent survey of companies found that $25 \%$ of new hires came from national job search websites and nearly all surveyed companies attributed at least one hire in 2010 to the website used in this audit (Crispin and Mehler 2011). Additionally, data from 
2006 found that $62 \%$ of individuals between $18-28$ years old used the internet for job searches, a figure that had almost certainly increased by the time of this data collection (Brown 2008). It is unclear if there are differences by college selectivity in the likelihood of using the internet for job search; no data to fully adjudicate this question seem to exist.

Another limitation of this study is that I cannot attribute the effect of educational credentials to a specific mechanism, whether human or cultural capital. As stated above, social capital as a mechanism has been effectively ruled out. In most cases, employers privilege candidates with a degree from an elite university, as evidenced by the quantitative results and qualitative email responses, but it is unclear if employers do so because they believe these candidates have obtained superior knowledge and skills or because they believe these candidates come from the proper social background. However, employers are also less likely to contact candidates with a degree from an elite university for customer service jobs, which suggests that employers may have concerns about job mismatch and overqualified workers. Future research could gain traction on these mechanisms with more in-depth qualitative analysis (see Rivera 2012 for one such study in the context of elite firms).

A final point is that this study is somewhat circumscribed by time, location, and the chosen set of universities, so it is difficult to compare this study with prior work on educational credentials in the labor market. Although the results differ from some of the most methodologically advanced survey research on college selectivity, prior research has focused on the employment outcomes of older cohorts of college graduates later in their careers. Both time period and age might explain the differences in findings but we cannot be certain whether qualitative differences in educational credentials matter more now than in previous years because of quantitative changes in educational credentials, or if qualitative aspects of educational credentials simply matter less later in an individual's career. Moreover, differences in the 
measurement of outcomes could be to blame; research on how job interviews translate to actual job offers and wages is limited (although see Petersen, Saporta, and Seidel 2000; Barron, Bishop, and Dunkelberg 1985). Finally, during the data collection labor market conditions were tight and unemployment was still somewhat high nationwide, potentially giving employers more power and thus providing a high-end estimation of effects.

This research addresses a number of gaps in our knowledge concerning educational credentials and racial inequality and raises a number of important issues. The results suggest that other scholars should be more cautious when measuring college education as one category of a variable. Although this research only tests employment outcomes at the entry-level stage, college selectivity may be important at other stages of employment and for other outcomes. Furthermore, education, even an elite education, does not erase racial inequality during the preliminary stages of the employment process. Other research finds that overall racial inequality in the labor market increases over the career and is typically lowest at the point of entry into the labor market, suggesting that future research should examine whether graduating from an elite university may help to attenuate or exacerbate inequalities over time (Tomaskovic-Devey, Thomas, and Johnson 2005).

Overall, this research contributes to our theoretical and empirical understanding of the possibilities and limits of education in reducing social inequality. Randall Collins was not wrong in 1979 when he described education as "the most important determinant yet discovered of how far one will go in today's world” (3). Since then, young black men and women pursuing the American Dream have gained an increasingly larger share of college degrees in the educational credentials arms race (Gaddis 2013). However, education apparently has its limits because even a Harvard degree cannot make DaQuan as enticing as Charlie to employers. 


\section{ENDNOTES}

1. The exact National University Rankings were: (1) Harvard, (5) Stanford, (10) Duke, (94) UMass-Amherst, (97) UC-Riverside, and (190) UNC-Greensboro.

2. Using survey experiments, I find that individuals accurately classify race for these particular names (see Gaddis 2014).

3. One additional potential human capital difference is GPA. Each resume includes a GPA based on the requirements listed for graduation with honors (cum laude) for each school and does not vary within school.

4. Additionally, simply sending more than two applications to a single employer compounds this problem and increases the amount of time a single employer must spend reviewing applications, raising additional ethical concerns. Experiment discovery by employers introduces other ethical concerns such as termination or other economic harm of individual employees involved in the audit (see Gaddis 2013).

5. Cover letter type, resume template, employment history, and application order also vary equally across pairs.

6. Audit studies often do not discuss the differences in these effects. Within-pair effects are directly observed but between-pair effects are indirectly observed.

7. Additionally, I calculate total response rates (either email or phone).

8. In these cases I sent a third test application with credentials that did not meet the qualifications of the posted job. If the third candidate received an identical response I removed any employer response in the data.

9. Although response rates vary somewhat by social class, gender, college major, and region, detailed examination of those results is beyond the scope of this article. Both the design of the audit method and the logistic regression models control for these characteristics to avoid biased coefficients.

10. The total response percentage does not equal email plus phone because some employers responded by both email and phone.

11. These two categories are never statistically different across any employer response type.

12. The differences between white candidates with a degree from an elite university and all other candidates are statistically significant $(\mathrm{p}<0.05$ for black candidates with a degree from an elite university; $\mathrm{p}<0.01$ for white candidates with a degree from a less selective university; $\mathrm{p}<0.001$ for black candidates with a degree from a less selective university). The differences between black candidates with a degree from a less selective university and all other candidates are statistically significant $(\mathrm{p}<0.01$ for white candidates with a degree from a less selective university; $\mathrm{p}<0.001$ for white candidates with a degree from an elite university and black candidates with a degree from an elite university).

13. I find no significant differences in region or occupation type between job advertisements that include salary information and those that do not (results available upon request).

14. The models presented here include dummy variables for the occupational categories of each job because both salaries and responses are correlated with occupational categories. Without this control, the coefficients for black candidate are larger in size and the coefficients for candidate with a degree from an elite university remain largely unchanged (results available upon request). This suggests that the type of job for which black candidates receive responses accounts for some of the difference in listed salaries. However, candidates with a degree from an elite university appear to receive responses for higher salary jobs regardless of the job type.

15. Although sales also has a higher than average listed salary range the range has significant variation. 
16. Moss and Tilly (2001) suggest that blacks may be at a disadvantage for jobs involving direct customer interaction. Although I find no evidence to support this claim, the job advertisements often make it difficult to distinguish between face-to-face customer interaction and other types of interaction which may make this a somewhat noisy measure. 


\section{REFERENCES}

Ahmed, Ali M., and Mats Hammarstedt. 2008. "Discrimination in the Rental Housing Market: A Field Experiment on the Internet.” Journal of Urban Economics, 64(2):362-72.

Alon, Sigal, and Yitchak Haberfeld. 2007. "Labor Force Attachment and the Evolving Wage Gap Between White, Black, and Hispanic Young Women.” Work and Occupations, 34(4):369-98.

Alon, Sigal, and Marta Tienda. 2005. "Assessing the 'Mismatch' Hypothesis: Differences in College Graduation Rates by Institutional Selectivity.” Sociology of Education, 78(4):294-315.

Alon, Sigal, and Marta Tienda. 2007. "Diversity, Opportunity, and the Shifting Meritocracy in Higher Education.” American Sociological Review, 72(4):487-511.

Altonji, Joseph G., Erica Blom, and Costas Meghir. 2012. "Heterogeneity in Human Capital Investments: High School Curriculum, College Major, and Careers.” Annual Review of Economics, 4:185-223.

Barron, John M., John Bishop, and William C. Dunkelberg. 1985. "Employer Search: The Interviewing and Hiring of New Employees." The Review of Economics and Statistics, 67(1):43-52.

Baum, Sandy, Jennifer Ma, and Kathleen Payea. 2010. Education Pays 2010: The Benefits of Higher Education for Individuals and Society. CollegeBoard Advocacy \& Policy Center. Retrieved October 15, 2010 from http://trends.collegeboard.org.

Behrman, Jere R., Mark R. Rosenzweig, and Paul Taubman. 1996. "College Choice and Wages: Estimates Using Data on Female Twins.” The Review of Economics and Statistics, 78(4):672-85.

Bendick, Marc, Charles W. Jackson, and Victor A. Reinoso. 1994. "Measuring Employment Discrimination Through Controlled Experiments.” Review of Black Political Economics 23(1):25-48.

Bertrand, Marianne, and Sendhil Mullainathan. 2004. “Are Emily and Greg More Employable than Lakisha and Jamal? A Field Experiment on Labor Market Discrimination.” The American Economic Review, 94(4):991-1013.

Black, Dan A., and Jeffrey A. Smith. 2004. "How Robust is the Evidence on the Effects of College Quality? Evidence from Matching.” Journal of Econometrics, 121(1):99-124.

Blank, R. M., M. Dabady, and C. F. Citro (Eds.). 2004. Measuring Racial Discrimination. Washington, DC: The National Academies Press.

Bobo, Lawrence. 2001. "Racial Attitudes and Relations at the Close of the Twentieth Century." in N. Smelser, W. J. Wilson, and F. Mitchell, eds., America Becoming: Racial Trends and Their Consequences. Washington, D.C.: National Academy Press

Bonilla-Silva, Eduardo. 2010. Racism Without Racists. $3^{\text {rd }}$ edition. UK: Rowman and Littlefield.

Bowen, William G., and Derek Bok. 1998. The Shape of the River: Long-Term Consequences of Considering Race in College and University Admissions. Princeton University Press. Princeton, NJ.

Bradbury, Katharine L. 2002. "Education and Wages in the 1980s and 1990s: Are All Groups Moving Up Together?” New England Economic Review, First Quarter: 19-46.

Braddock, Jomills Henry, and James M. McPartland. 1987. "How Minorities Continue to be Excluded from Equal Opportunities: Research on Labor Markets and Institutional Barriers.” Journal of Social Issues, 43(1):5-39.

Brand, Jennie E., and Charles N. Halaby. 2006. "Regression and Matching Estimates of the Effects of Elite College Attendance on Educational and Career Achievement.” Social Science Research, 35(3):749-70.

Brand, Jennie E., and Yu Xie. 2010. "Who Benefits Most from College? Evidence for Negative Selection in Heterogeneous Economic Returns to Higher Education.” American Sociological Review,75(2):273-302.

Brewer, Dominic J., and Ronald G. Ehrenberg. 1996. “Does it Pay to Attend an Elite Private College? Evidence from the Senior Class of 1980.” In: Polachek, S. (Ed.), Research in Labor Economics, Vol. 15. JAI Press, Greenwich, CT, pp. 239-71.

Brewer, Dominic J., Eric R. Eide, and Ronald G. Ehrenberg. 1999. "Does it Pay to Attend an Elite College? Cross Cohort Evidence on the Effects of College Type on Earnings.” Journal of Human Resources 34(1):104-23. 
Brown, Lauren E. 2008. “Job Seekers on the Internet: An Empirical Analysis.” Unpublished dissertation, Brandeis University.

Brown, Susan K., and Charles Hirschman. 2006. "The End of Affirmative Action in Washington State and Its Impact on the Transition from High School to College.” Sociology of Education, 79(2):106-30.

Butler, Daniel M., and David E. Broockman. 2011. "Do Politicians Racially Discriminate Against Constituents? A Field Experiment on State Legislators.” American Journal of Political Science, 55(3):463-77.

Cancio, A. Silvia, T. David Evans, and David J. Maume. 1996. "Reconsidering the Declining Significance of Race: Racial Differences in Early Career Wages.” American Sociological Review, 61(4):541-56.

Card, David, and Alan Krueger. 2005. "Would the Elimination of Affirmative Action Affect Highly Qualified Minority Applicants? Evidence from California and Texas.” Industrial and Labor Relations Review, 58(3):416-34.

Carnevale, Anthony P., Jeff Strohl, and Michelle Melton. 2011. What's it Worth? The Economic Value of College Majors. Georgetown University Center on Education and the Workforce. Retrieved June 1, 2011 from http://cew.georgetown.edu/whatsitworth/.

Carnevale, Anthony P., and Stephen J. Rose. 2003. "Socioeconomic Status, Race/Ethnicity, and Selective College Admissions.” In Richard D. Kahlenberg (Ed.), America’s Untapped Resource: LowIncome Students in Higher Education. New York, NY: The Century Foundation.

Collins, Randall. 1979. The Credential Society: An Historical Sociology of Education and Stratification. Academic Press. New York, NY.

Cooper, Samuel T., and Elchanan Cohn. 1997. "Internal Rates of Return to College Education in the United States by Sex and Race.” Journal of Education Finance, 23(1):101-133.

Crispin, Gerry, and Mark Mehler. 2011. "10th Annual CareerXroads Source of Hire Report: By the Numbers.” Retrieved March 14, 2013 from http://www.careerxroads.com/news/SourcesOfHire11.pdf.

Dale, Stacy, and Alan B. Krueger. 2002. "Estimating the Payoff to Attending a More Selective College: An Application of Selection on Observables and Unobservables." Quarterly Journal of Economics, 117(4):1491-1527.

Dale, Stacy, and Alan B. Krueger. 2011. "Estimating the Return to College Selectivity over the Career Using Administrative Earning Data.” Working Paper.

Espenshade, Thomas J., and Chang Y. Chung. 2005. "The Opportunity Cost of Admission Preferences at Elite Universities.” Social Science Quarterly, 85(5):1422-46.

Farkas, George, and Kevin Vicknair. 1996. "Appropriate Tests of Racial Wage Discrimination Require Controls for Cognitive Skill: Comment on Cancio, Evans, and Maume.” American Sociological Review, 61(4):557-60.

Fryer, Roland G., and Steven D. Levitt. 2004. "The Causes and Consequences of Distinctively Black Names.” Quarterly Journal of Economics, 119(3):767-805.

Gaddis, S. Michael. 2013. A Matter of Degrees: Educational Credentials and Race and Gender Discrimination in the Labor Market. Chapel Hill, NC: The University of North Carolina. Unpublished dissertation.

Gaddis, S. Michael. 2014. "By Any Other Name: Two Experiments to Examine Perceptions of Race and Social Class from Names.” Working paper.

Gerber, Theodore P., and Sin Yi Cheung. 2008. "Horizontal Stratification in Postsecondary Education: Forms, Explanations, and Implications.” Annual Review of Sociology, 34:299-318.

Gonzalez, Richard. 2009. Data Analysis for Experimental Design. New York, NY: The Guilford Press.

Heckman, James J. 1998. “Detecting Discrimination.” Journal of Economic Perspectives, 12(2):101-16.

Heckman, James J., and Peter Siegelman. 1993. "The Urban Institute Audit Studies: Their Methods and Findings.” in Clear and Convincing Evidence: Measurement of Discrimination in America, eds. M. Fix and R. J. Stucyk. Lanham, MD: Urban Institute Press.

Hoekstra, Mark 2009. "The Effect of Attending the Flagship State University on Earnings: A Discontinuity-Based Approach.” The Review of Economics and Statistics, 91(4): 717-24.

Hogan, Bernie, and Brent Berry. 2011. "Racial and Ethnic Biases in Rental Housing: An Audit Study of Online Apartment Listings.” City and Community, 10(4):351-72. 
Hout, Michael. 2012. "Social and Economic Returns to College Education in the United States.” Annual Review of Sociology, 38:379-400.

Jones, F. L., and J. Kelley. 1984. "Decomposing Difference Between Groups: A Cautionary Note on Measuring Discrimination.” Sociological Methods and Research, 12(3):323-43.

Kirschenman, Joleen, and Kathryn M. Neckerman. 1991. "'We'd Love to Hire Them But...': The Meaning of Race to Employers.” In Christopher Jencks and Paul E. Peterson (Eds.), The Urban Underclass, (pp. 203-32). Washington, D.C.: Brookings.

Kutner, Michael H., Christopher J. Nachtsheim, John Neter, and William Li. 2004. Applied Linear Statistics Models. $5^{\text {th }}$ edition. New York, NY: McGraw-Hill.

Lauster, Nathanael, and Adam Easterbrook. 2011. "No Room for New Families? A Field Experiment Measuring Rental Discrimination against Same-Sex Couples and Single Parents.” Social Problems, 58(3):389-409.

Long, Mark C. 2007. "Affirmative Action and its Alternatives in Public Universities: What Do We Know?” Public Administration Review, 67(2):315-330.

Long, Mark C. 2008. “College Quality and Early Adult Outcomes.” Economics of Education Review, 27(5):588-602.

Long, Mark C. 2010. “Changes in the Returns to Education and College Quality.” Economics of Education Review, 29(3):338-47.

Loury, Linda D., and David Garman. 1995. “College Selectivity and Earnings.” Journal of Labor Economics, 13(2):289-308.

Lucas, Samuel R. 2008. Theorizing Discrimination in an Era of Contested Prejudice: Discrimination in the United States. Philadelphia, PA: Temple University Press.

Massey, Douglas S. 2007. Categorically Unequal: The American Stratification System. New York, NY: The Russell Sage Foundation.

Monks, James. 2000. "The Returns to Individual and College Characteristics: Evidence from the National Longitudinal Survey of Youth.” Economics of Education Review, 19(3):279-89.

Moss, Philip, and Chris Tilly. 2001. Stories Employers Tell: Race, Skill and Hiring in America. New York, NY: Russell Sage Foundation.

Mullen, Ann L. 2010. Degrees of Inequality: Culture, Class, and Gender in American Higher Education. Baltimore, MD: The Johns Hopkins University Press.

Neal, Derek, and William Johnson. 1996. "The Role of Premarket Factors in Black-White Wage Differences.” Journal of Political Economy, 104(5):869-95.

O'Neill, June. 1990. "The Role of Human Capital in Earnings Differences between Black and White Men.” Journal of Economic Perspectives, 4(4):25-45.

Pager, Devah. 2003. “The Mark of a Criminal Record.” American Journal of Sociology, 108(5):937-75.

Pager, Devah. 2007a. Marked: Race, Crime and Finding Work in an Era of Mass Incarceration. Chicago, IL: The University of Chicago Press.

Pager, Devah. 2007b. "The Use of Field Experiments for Studies of Employment Discrimination: Contributions, Critiques, and Directions for the Future.” The Annals of the American Academy of Political and Social Science, 609:104-33.

Pager, Devah, and Lincoln Quillian. 2005. "Walking the Talk? What Employers Say Versus What They Do.” American Sociological Review, 70(3):355-80.

Pager, Devah, Bruce Western, and B. Bonikowski. 2009. "Discrimination in a Low Wage Labor Market: A Field Experiment.” American Sociological Review, 74(5):777-99.

Petersen, Trond. Ishak Saporta, and Marc-David L. Seidel. 2000. "Offering a Job: Meritocracy and Social Networks.” American Journal of Sociology, 106(3):763-816.

Quillian, Lincoln. 2006. "New Approaches to Understanding Racial Prejudice and Discrimination.” Annual Review of Sociology, 32:299-328.

Rivera, Lauren A. 2011. "Ivies, Extracurriculars, and Exclusion: Credentialism in Elite Labor Markets.” Research in Social Stratification and Mobility, 29(1):71-90.

Rivera, Lauren A. 2012. "Hiring as Cultural Matching: The Case of Elite Professional Service Firms." American Sociological Review, 77(6):999-1022.

Schuman, H., C. Steeh, L. Bobo, and M. Krysan. 2001. Racial Attitudes in America: Trends and 
Interpretations. Revised Edition. Cambridge, MA: Harvard University Press

Soares, Joseph A. 2007. The Power of Privilege: Yale and America's Elite Colleges. Stanford, CA: Stanford University Press.

Tomaskovic-Devey, Donald, Melvin Thomas, and Kecia Johnson. 2005. "Race and the Accumulation of Human Capital across the Career: A Theoretical Model and Fixed-Effects Application.” American Journal of Sociology, 111(1):58-89.

Tilcsik, Andras. 2011. "Pride and Prejudice: Employment Discrimination against Openly Gay Men in the United States.” American Journal of Sociology, 117(2):586-626.

U.S. Census Bureau. 2008. “Census Report Data File A: Top 1000 Names.” Retrieved November 13, 2010.” (http://www.census.gov/genealogy/www/data/2000surnames/Top1000.xls)

U.S. News and World Report 2011. "National University Rankings.” New York, NY: U.S. News and World Report. Retrieved March 1, 2011 (http://colleges.usnews.rankingsandreviews.com/ best-colleges/rankings/national-universities).

Waldinger, Roger. 1997. "Black/Immigrant Competition Re-Assessed: New Evidence from Los Angeles.” Sociological Perspectives, 40(3):365-86.

Wilson, Franklin D., Marta Tienda, and Lawrence Wu. 1995. "Race and Unemployment - Labor-Market Experiences of Black and White Men, 1968-1988.” Work and Occupations, 22(3):245-70.

Yinger, J. 1995. Closed Doors, Opportunities Lost: The Continuing Costs of Housing Discrimination. New York, NY: Russell Sage Foundation.

Zhang, Liang. 2008. “Gender and Racial Gaps in Earnings among Recent College Graduates.” Review of Higher Education, 32(1):51-72. 
Table 1. Basic Matching Procedure

\begin{tabular}{|c|c|c|c|c|c|c|c|c|c|c|}
\hline ID & $\begin{array}{l}\text { A1 } \\
\text { Race }\end{array}$ & $\begin{array}{l}\text { A1 } \\
\text { Univ. } \\
\text { Type }\end{array}$ & $\begin{array}{l}\text { A1 } \\
\text { Gender }\end{array}$ & $\begin{array}{l}\text { A1 } \\
\text { Social } \\
\text { Class }\end{array}$ & $\begin{array}{l}\text { A1 } \\
\text { Major }\end{array}$ & $\begin{array}{l}\text { A2 } \\
\text { Race }\end{array}$ & $\begin{array}{l}\text { A2 } \\
\text { Univ. } \\
\text { Type }\end{array}$ & $\begin{array}{l}\text { A2 } \\
\text { Gender }\end{array}$ & $\begin{array}{l}\text { A2 } \\
\text { Social } \\
\text { Class }\end{array}$ & $\begin{array}{l}\text { A2 } \\
\text { Major }\end{array}$ \\
\hline 01 & White & LS & Male & Upper & Econ & Black & Elite & Male & Upper & Econ \\
\hline 02 & White & LS & Male & Upper & Psych & Black & Elite & Male & Upper & Psych \\
\hline 03 & White & LS & Male & Mid & Econ & Black & Elite & Male & Mid & Econ \\
\hline 04 & White & LS & Male & Mid & Psych & Black & Elite & Male & Mid & Psych \\
\hline 05 & White & LS & Male & Low & Econ & Black & Elite & Male & Low & Econ \\
\hline 06 & White & LS & Male & Low & Psych & Black & Elite & Male & Low & Psych \\
\hline 07 & White & LS & Female & Upper & Econ & Black & Elite & Female & Upper & Econ \\
\hline 08 & White & LS & Female & Upper & Psych & Black & Elite & Female & Upper & Psych \\
\hline 09 & White & LS & Female & Mid & Econ & Black & Elite & Female & Mid & Econ \\
\hline 10 & White & LS & Female & Mid & Psych & Black & Elite & Female & Mid & Psych \\
\hline 11 & White & LS & Female & Low & Econ & Black & Elite & Female & Low & Econ \\
\hline 12 & White & LS & Female & Low & Psych & Black & Elite & Female & Low & Psych \\
\hline 13 & White & Elite & Male & Upper & Econ & Black & LS & Male & Upper & Econ \\
\hline 14 & White & Elite & Male & Upper & Psych & Black & LS & Male & Upper & Psych \\
\hline 15 & White & Elite & Male & Mid & Econ & Black & LS & Male & Mid & Econ \\
\hline 16 & White & Elite & Male & Mid & Psych & Black & LS & Male & Mid & Psych \\
\hline 17 & White & Elite & Male & Low & Econ & Black & LS & Male & Low & Econ \\
\hline 18 & White & Elite & Male & Low & Psych & Black & LS & Male & Low & Psych \\
\hline 19 & White & Elite & Female & Upper & Econ & Black & LS & Female & Upper & Econ \\
\hline 20 & White & Elite & Female & Upper & Psych & Black & LS & Female & Upper & Psych \\
\hline 21 & White & Elite & Female & Mid & Econ & Black & LS & Female & Mid & Econ \\
\hline 22 & White & Elite & Female & Mid & Psych & Black & LS & Female & Mid & Psych \\
\hline 23 & White & Elite & Female & Low & Econ & Black & LS & Female & Low & Econ \\
\hline 24 & White & Elite & Female & Low & Psych & Black & LS & Female & Low & Psych \\
\hline
\end{tabular}

Note: A1 = applicant 1, A 2= applicant 2, LS= less selective. These 24 pairs represent the total set of candidate pairs that applied to jobs across the three regions. 
Table 2. Applicant Descriptive Statistics

\begin{tabular}{|c|c|c|c|c|c|c|}
\hline & \multicolumn{2}{|c|}{ Applicant 1} & \multicolumn{2}{|c|}{ Applicant 2} & \multicolumn{2}{|c|}{ Total } \\
\hline & $\mathrm{N}$ & $\%$ (mean) & $\mathrm{N}$ & $\%$ (mean) & $\mathrm{N}$ & $\%$ (mean) \\
\hline White & 469 & $49.3 \%$ & 483 & $50.7 \%$ & 952 & $50.0 \%$ \\
\hline Black & 483 & $50.7 \%$ & 469 & $49.3 \%$ & 952 & $50.0 \%$ \\
\hline Elite University & 482 & $50.6 \%$ & 470 & $49.4 \%$ & 952 & $50.0 \%$ \\
\hline Less Selective University & 470 & $49.4 \%$ & 482 & $50.6 \%$ & 952 & $50.0 \%$ \\
\hline Male & 475 & $49.9 \%$ & 475 & $49.9 \%$ & 950 & $49.9 \%$ \\
\hline Female & 477 & $50.1 \%$ & 477 & $50.1 \%$ & 954 & $50.1 \%$ \\
\hline Upper Class & 322 & $33.8 \%$ & 322 & $33.8 \%$ & 644 & $33.8 \%$ \\
\hline Middle Class & 309 & $32.5 \%$ & 309 & $32.5 \%$ & 618 & $32.5 \%$ \\
\hline Lower Class & 321 & $33.7 \%$ & 321 & $33.7 \%$ & 642 & $33.7 \%$ \\
\hline Region - Southeast & 318 & $33.4 \%$ & 318 & $33.4 \%$ & 636 & $33.4 \%$ \\
\hline Region - Northeast & 320 & $33.6 \%$ & 320 & $33.6 \%$ & 640 & $33.6 \%$ \\
\hline Region - West & 314 & $33.0 \%$ & 314 & $33.0 \%$ & 628 & $33.0 \%$ \\
\hline Home Region & 673 & $70.7 \%$ & 673 & $70.7 \%$ & 1346 & $70.7 \%$ \\
\hline Out of Home Region & 279 & $29.3 \%$ & 279 & $29.3 \%$ & 558 & $29.3 \%$ \\
\hline Major - Economics & 479 & $50.3 \%$ & 479 & $50.3 \%$ & 958 & $50.3 \%$ \\
\hline Major - Psychology & 473 & $49.7 \%$ & 473 & $49.7 \%$ & 946 & $49.7 \%$ \\
\hline Response - Email & 74 & $7.8 \%$ & 67 & $7.0 \%$ & 141 & $7.4 \%$ \\
\hline Response - Phone & 76 & $8.0 \%$ & 80 & $8.4 \%$ & 156 & $8.2 \%$ \\
\hline Response - Both & 32 & $3.4 \%$ & 35 & $3.7 \%$ & 67 & $3.5 \%$ \\
\hline $\begin{array}{l}\text { Response - Total (either } \\
\text { email or phone) }\end{array}$ & 118 & $12.4 \%$ & 112 & $11.8 \%$ & 230 & $12.1 \%$ \\
\hline Removed & 56 & $5.6 \%$ & 56 & $5.6 \%$ & 112 & $5.6 \%$ \\
\hline $\mathrm{N}$ & 952 & $94.4 \%$ & 952 & $94.4 \%$ & 1904 & $94.4 \%$ \\
\hline
\end{tabular}

Note: Applicant 1 and 2 refers to the order of application to a job within a pair. Removed indicates attrition from the sample - an employer removed a job advertisement before one or both applicants could apply for the job. 
Table 3. Job Advertisement Descriptive Statistics

\begin{tabular}{|c|c|c|c|c|c|c|c|}
\hline & \multicolumn{2}{|r|}{ Set 1} & \multicolumn{2}{|c|}{ Set 2} & \multirow{2}{*}{$\begin{array}{c}\text { Difference } \\
\text { p-value }\end{array}$} & \multicolumn{2}{|c|}{ Total } \\
\hline & $\mathrm{N}$ & $\%$ (mean) & $\mathrm{N}$ & $\%$ (mean) & & $\mathrm{N}$ & $\%$ (mean) \\
\hline \multicolumn{8}{|l|}{ Occupational Category } \\
\hline Administrative Assistant & 73 & $15.4 \%$ & 72 & $15.0 \%$ & 0.863 & 145 & $15.2 \%$ \\
\hline Analyst & 48 & $10.2 \%$ & 45 & $9.4 \%$ & 0.696 & 93 & $9.8 \%$ \\
\hline Clerical & 39 & $8.3 \%$ & 43 & $9.0 \%$ & 0.688 & 82 & $8.6 \%$ \\
\hline Customer Service & 82 & $17.3 \%$ & 91 & $19.0 \%$ & 0.507 & 173 & $18.2 \%$ \\
\hline Human Resources & 26 & $5.5 \%$ & 31 & $6.5 \%$ & 0.527 & 57 & $6.0 \%$ \\
\hline Managerial & 25 & $5.3 \%$ & 24 & $5.0 \%$ & 0.848 & 49 & $5.1 \%$ \\
\hline Other - Kids & 27 & $5.7 \%$ & 21 & $4.4 \%$ & 0.351 & 48 & $5.0 \%$ \\
\hline Other - Physical & 12 & $2.5 \%$ & 13 & $2.7 \%$ & 0.865 & 25 & $2.6 \%$ \\
\hline Other & 29 & $6.1 \%$ & 28 & $5.9 \%$ & 0.853 & 57 & $6.0 \%$ \\
\hline Sales & 112 & $23.7 \%$ & 111 & $23.2 \%$ & 0.854 & 223 & $23.4 \%$ \\
\hline Listed Salary - Low & 141 & $\$ 30,977$ & 148 & $\$ 31,790$ & 0.438 & 289 & $\$ 31,393$ \\
\hline Listed Salary - Mean & 141 & $\$ 34,306$ & 148 & $\$ 34,834$ & 0.640 & 289 & $\$ 34,576$ \\
\hline Listed Salary - High & 141 & $\$ 37,635$ & 148 & $\$ 37,879$ & 0.855 & 289 & $\$ 37,760$ \\
\hline Removed & 31 & $6.2 \%$ & 25 & $5.0 \%$ & 0.410 & 56 & $5.6 \%$ \\
\hline $\mathrm{N}$ & 473 & $93.9 \%$ & 479 & $95.0 \%$ & & 952 & $94.4 \%$ \\
\hline
\end{tabular}

Note: Set 1 refers to black candidates with a degree from an elite university and white candidates with a degree from a less selective university (Pair IDs 1-12 in Table 1); set 2 refers to white candidates with a degree from an elite university and black candidates with a degree from a less selective university (Pair IDs 13-24 in Table 1). Difference indicates the p-value of a two-tailed t-test examining the difference in values between Sets 1 and 2. Removed indicates attrition from the sample - an employer removed a job advertisement before one or both applicants could apply for the job. 


\begin{tabular}{|c|c|c|c|}
\hline & Email & Phone & Total \\
\hline \multirow[t]{2}{*}{ Black (ref: White) } & $0.677^{* *}$ & $0.616^{* * *}$ & $0.628 * * *$ \\
\hline & $(0.086)$ & $(0.090)$ & $(0.071)$ \\
\hline \multirow[t]{2}{*}{ Elite (ref: Less Selective) } & $1.472 * *$ & $2.007 * * *$ & $1.841^{* * *}$ \\
\hline & $(0.188)$ & $(0.300)$ & $(0.211)$ \\
\hline \multirow[t]{2}{*}{ Female (ref: Male) } & 0.923 & 0.864 & 0.956 \\
\hline & $(0.200)$ & $(0.166)$ & (0.161) \\
\hline \multirow[t]{2}{*}{ Lower-class (ref: Upper/Middle) } & 0.599* & $0.560 *$ & $0.607 *$ \\
\hline & $(0.150)$ & $(0.132)$ & $(0.120)$ \\
\hline \multirow[t]{2}{*}{ Major - Psychology (ref: Economics) } & 0.853 & 0.825 & 0.860 \\
\hline & $(0.185)$ & $(0.159)$ & $(0.145)$ \\
\hline \multirow[t]{2}{*}{ Region - Northeast (ref: Southeast) } & $1.606+$ & 1.412 & $1.475+$ \\
\hline & $(0.414)$ & $(0.326)$ & $(0.298)$ \\
\hline \multirow[t]{2}{*}{ Region - West } & 0.989 & 1.044 & 1.052 \\
\hline & $(0.278)$ & $(0.257)$ & $(0.226)$ \\
\hline \multirow[t]{2}{*}{ Out of Home Region } & 0.881 & 1.045 & 1.015 \\
\hline & $(0.211)$ & $(0.221)$ & $(0.186)$ \\
\hline \multirow[t]{2}{*}{ Application submission $\left(2^{\text {nd }}\right)$} & 0.897 & 1.062 & 0.943 \\
\hline & $(0.114)$ & $(0.152)$ & $(0.105)$ \\
\hline Constant & $0.093 * * *$ & $0.086 * * *$ & $0.135^{* * *}$ \\
\hline $\mathrm{N}$ & 1904 & 1904 & 1904 \\
\hline
\end{tabular}

Note: All completed cases are included. Regressions also control for resume type, cover letter type, and employment history type. Odds ratios shown. Cluster-corrected (job advertisement level) standard errors in parenthesis.

$+=\mathrm{p}<0.10, *=\mathrm{p}<0.05, * *=\mathrm{p}<0.01, * * *=\mathrm{p}<0.001$ 
Table 5. OLS Regressions Predicting Listed Salary Range of Job Advertisements

\begin{tabular}{|c|c|c|c|}
\hline & Low & Mean & High \\
\hline \multirow[t]{2}{*}{ Black (ref: White) } & $-3071.13^{* *}$ & $-2922.83 *$ & -2774.53 \\
\hline & $(1125.15)$ & $(1432.55)$ & $(1887.71)$ \\
\hline \multirow[t]{2}{*}{ Elite (ref: Less Selective) } & $2601.45^{*}$ & $3240.31 *$ & $3879.17 *$ \\
\hline & $(1291.51)$ & $(1407.58)$ & $(1627.26)$ \\
\hline \multirow[t]{2}{*}{ Female (ref: Male) } & -1405.89 & -1302.45 & -1199.01 \\
\hline & $(1730.20)$ & $(1956.30)$ & $(2393.46)$ \\
\hline \multirow[t]{2}{*}{ Lower-class (ref: Upper/Middle) } & -30.75 & -234.40 & -438.06 \\
\hline & $(1833.06)$ & $(1882.52)$ & $(2206.54)$ \\
\hline \multirow[t]{2}{*}{ Major - Psychology (ref: Economics) } & -2851.72 & -3173.60 & -3495.48 \\
\hline & $(1935.13)$ & $(2095.53)$ & $(2471.90)$ \\
\hline \multirow[t]{2}{*}{ Region - Northeast (ref: Southeast) } & $4759.56 *$ & $6711.64 * *$ & $8663.72 * *$ \\
\hline & $(2199.89)$ & $(2207.62)$ & $(2600.56)$ \\
\hline \multirow[t]{2}{*}{ Region - West } & $5469.73 *$ & $6971.03 *$ & $8472.33 *$ \\
\hline & $(2447.56)$ & (2728.59) & $(3231.61)$ \\
\hline \multirow[t]{2}{*}{ Out of Home Region } & 998.76 & 540.12 & 81.48 \\
\hline & $(2128.87)$ & $(2134.94)$ & $(2422.91)$ \\
\hline \multirow[t]{2}{*}{ Application submission $\left(2^{\text {nd }}\right)$} & 75.66 & 931.68 & 1787.70 \\
\hline & $(1183.06)$ & $(1274.26)$ & $(1482.12)$ \\
\hline \multirow[t]{2}{*}{ Both applicants received response } & -1535.42 & -820.04 & -104.66 \\
\hline & $(2210.75)$ & $(2335.30)$ & $(2756.79)$ \\
\hline Constant & $28994.00 * * *$ & $29741.61^{* * *}$ & $30489.22 * * *$ \\
\hline $\mathrm{N}$ & 93 & 93 & 93 \\
\hline
\end{tabular}

Note: Cases with no listed salary range or no employer response are dropped. Regressions also control for occupation type. resume type, cover letter type, and employment history type. Cluster-corrected (job advertisement level) standard errors in parenthesis.

$+=\mathrm{p}<0.10, *=\mathrm{p}<0.05, * *=\mathrm{p}<0.01, * * *=\mathrm{p}<0.001$ 
Table 6. Logistic Regressions Predicting Type of Occupation Response

$\begin{array}{cccc}\text { High Value } & \text { High Value } & \text { Customer } & \text { Customer } \\ \text { (1) } & \text { (2) } & \text { Service (1) } & \text { Service (2) }\end{array}$

\begin{tabular}{lcccc} 
Black (ref: White) & $0.561^{*}$ & $0.528^{* *}$ & 1.053 & 1.011 \\
& $(0.147)$ & $(0.130)$ & $(0.290)$ & $(0.268)$ \\
Elite (ref: Less Selective) & 1.194 & 1.311 & $0.533^{*}$ & $0.559^{*}$ \\
& $(0.319)$ & $(0.333)$ & $(0.137)$ & $(0.151)$ \\
Female (ref: Male) & 1.263 & 1.259 & 1.268 & 1.284 \\
& $(0.492)$ & $(0.489)$ & $(0.590)$ & $(0.600)$ \\
Lower-class (ref: Upper/Middle) & 0.989 & 0.960 & 1.431 & 1.396 \\
& $(0.458)$ & $(0.445)$ & $(0.932)$ & $(0.931)$ \\
Major - Psychology (ref: Economics) & 0.610 & 0.588 & 0.741 & 0.725 \\
& $(0.264)$ & $(0.257)$ & $(0.264)$ & $(0.344)$ \\
Region - Northeast (ref: Southeast) & 1.635 & 1.583 & 1.108 & 1.096 \\
& $(0.746)$ & $(0.717)$ & $(0.694)$ & $(0.683)$ \\
Region - West & 0.536 & 0.525 & 1.546 & 1.533 \\
& $(0.304)$ & $(0.300)$ & $(1.014)$ & $(1.003)$ \\
Out of Home Region & $0.384+$ & $0.380+$ & 1.198 & 1.217 \\
Application submission (2 ${ }^{\text {nd }}$ ) & $(0.188)$ & $(0.189)$ & $(0.543)$ & $(0.552)$ \\
& 0.852 & 0.835 & 1.124 & 1.126 \\
Both applicants received response & $(0.222)$ & $(0.218)$ & $(0.398)$ & $(0.400)$ \\
& & 1.356 & & 1.189 \\
Constant & & $(0.566)$ & & $(0.550$ \\
N & & & & \\
\hline
\end{tabular}

Note: Cases with no employer response are dropped. Models for high value occupations compare the likelihood of a response for managerial or analyst jobs versus all others. Models for customer service occupation compare the likelihood of a response for customer service jobs versus all others. Regressions also control for resume type, cover letter type, and employment history type. Odds ratios shown. Cluster-corrected (job advertisement level) standard errors in parenthesis.

$+=\mathrm{p}<0.10, *=\mathrm{p}<0.05, * *=\mathrm{p}<0.01, * * *=\mathrm{p}<0.001$ 
Figure 1. Employer Responses by College Selectivity

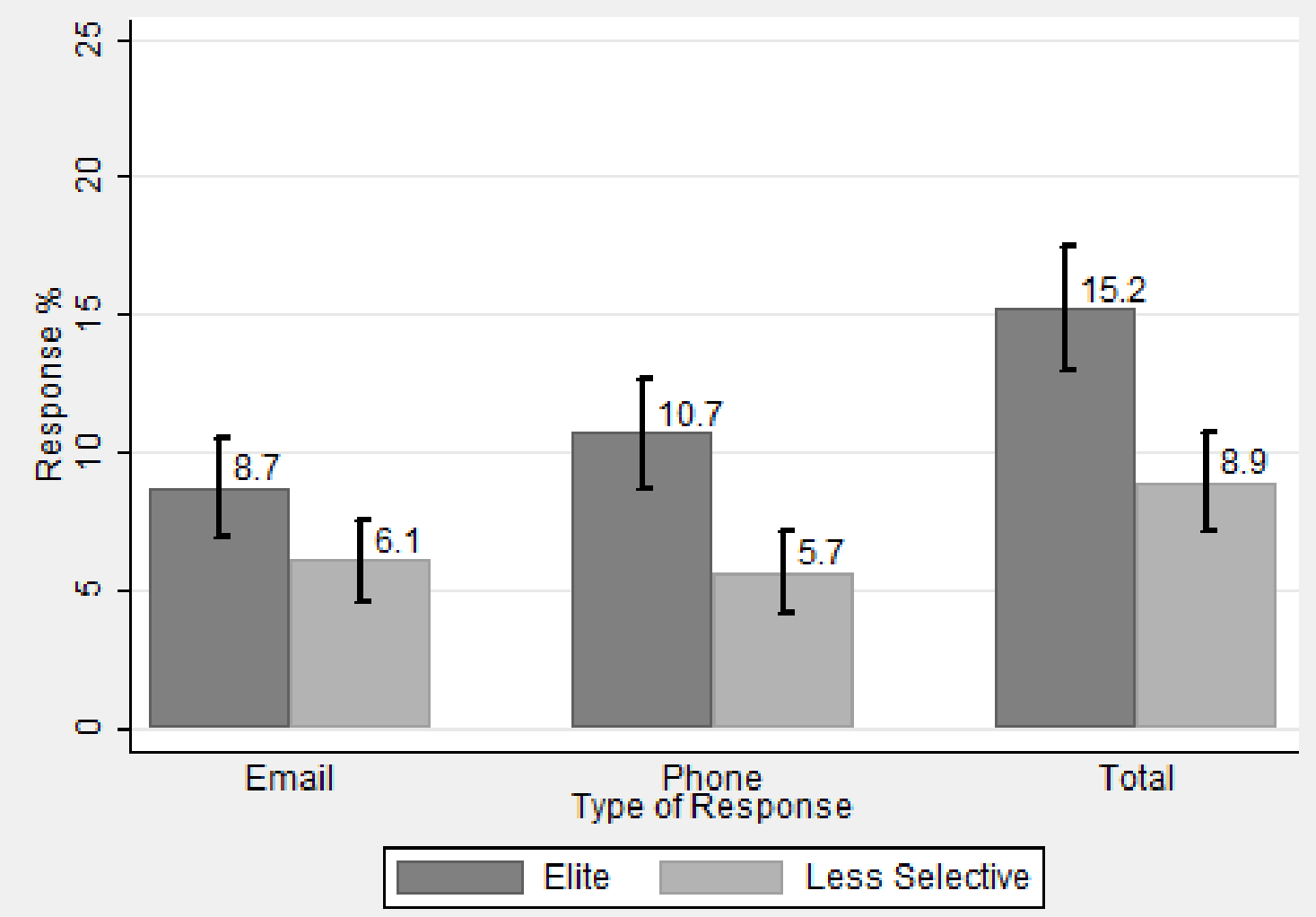

Note: The outer lines represent the 95\% confidence interval using a two-tailed Welch’s t-test. 
Figure 2. Employer Responses by Race

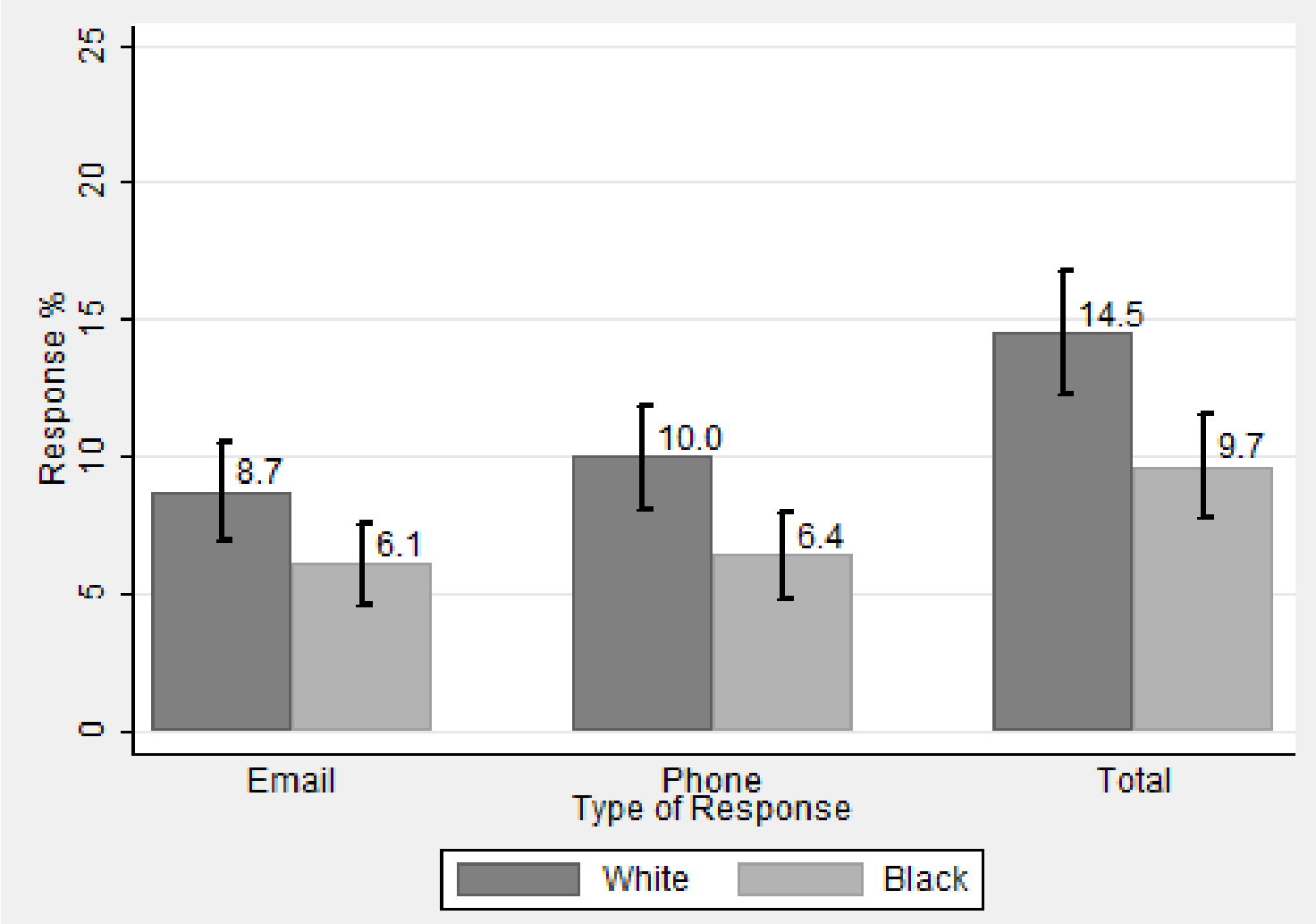

Note: The outer lines represent the 95\% confidence interval using a two-tailed Welch's t-test. 
Figure 3. Employer Responses by Race and College Selectivity

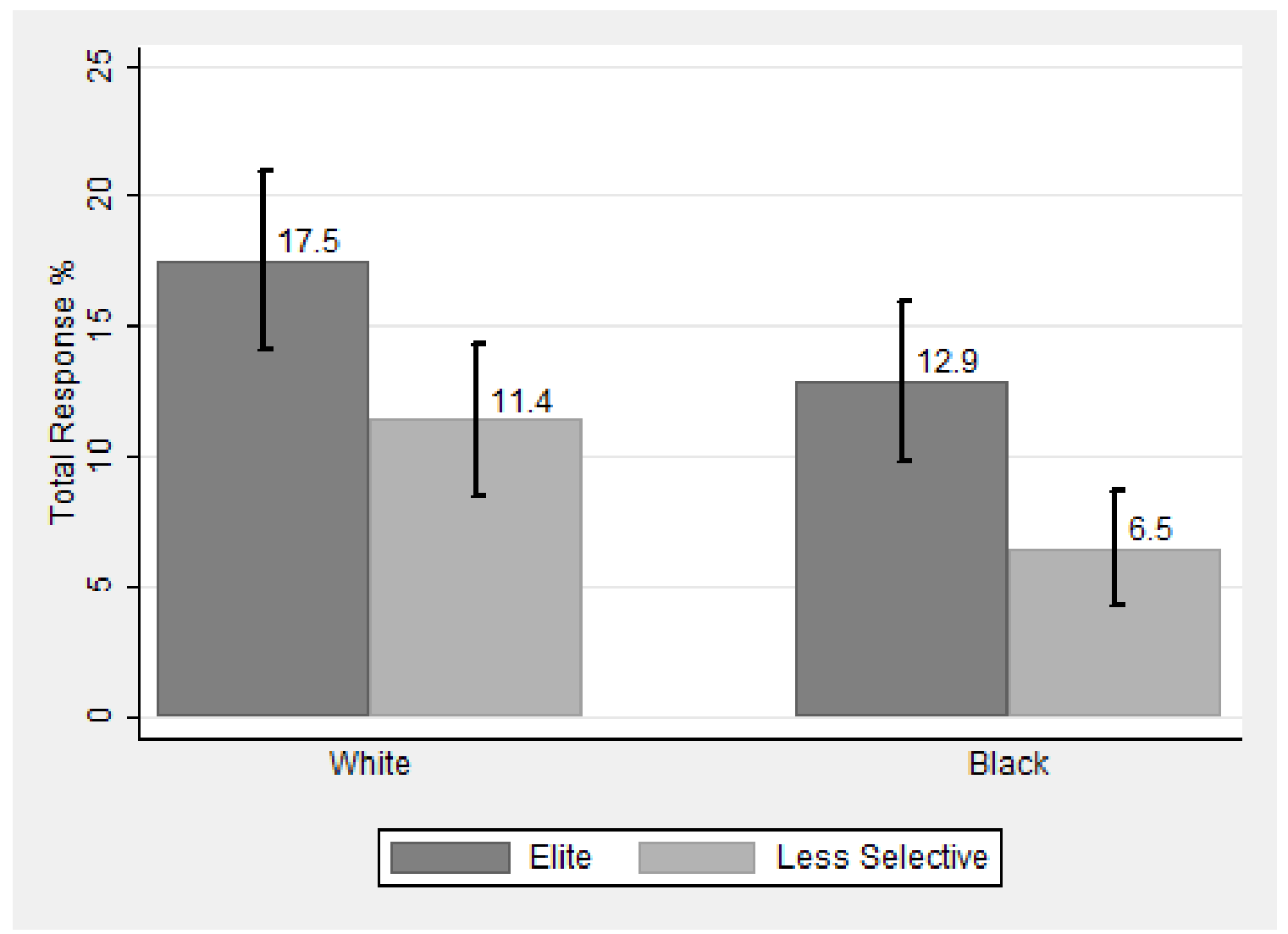

Note: The outer lines represent the 95\% confidence interval using a two-tailed paired t-test. The differences between white candidates with a degree from an elite university and all other candidates are statistically significant $(\mathrm{p}<0.05$ for black candidates with a degree from an elite university; $\mathrm{p}<0.01$ for white candidates with a degree from a less selective university; $\mathrm{p}<0.001$ for black candidates with a degree from a less selective university). The differences between black candidates with a degree from a less selective university and all other candidates are statistically significant ( $\mathrm{p}<0.01$ for white candidates with a degree from a less selective university; $p<0.001$ for white candidates with a degree from an elite university and black candidates with a degree from an elite university). 


\section{Appendix}

Appendix Table A1. First Names by Mother's Race and Mother's Education

\begin{tabular}{lcccc} 
& \% Black & \% White & $\% \leq$ HS & $\begin{array}{c}\% \geq \text { Some } \\
\text { College }\end{array}$ \\
\hline Jalen & $78.7 \%$ & $18.7 \%$ & $41.1 \%$ & $58.9 \%$ \\
Lamar & $86.1 \%$ & $12.7 \%$ & $69.2 \%$ & $30.8 \%$ \\
DaQuan & $87.3 \%$ & $12.7 \%$ & $90.1 \%$ & $9.9 \%$ \\
Nia & $84.4 \%$ & $14.3 \%$ & $38.8 \%$ & $61.2 \%$ \\
Ebony & $75.1 \%$ & $24.9 \%$ & $62.5 \%$ & $37.5 \%$ \\
Shanice & $92.9 \%$ & $7.1 \%$ & $82.1 \%$ & $17.9 \%$ \\
Caleb & $10.6 \%$ & $84.0 \%$ & $39.0 \%$ & $61.0 \%$ \\
Charlie & $10.2 \%$ & $85.4 \%$ & $64.2 \%$ & $35.8 \%$ \\
Ronny & $2.8 \%$ & $91.7 \%$ & $85.8 \%$ & $14.2 \%$ \\
Aubrey & $12.7 \%$ & $83.6 \%$ & $41.6 \%$ & $58.4 \%$ \\
Erica & $13.6 \%$ & $76.7 \%$ & $56.7 \%$ & $43.3 \%$ \\
Lesly & $7.7 \%$ & $91.5 \%$ & $87.1 \%$ & $12.9 \%$ \\
\hline
\end{tabular}

Note: Author's calculations from New York State Department of Health birth records, 2001-2003. 